\title{
Antithrombotic Therapy in Patients with ST-segment Elevation Myocardial Infarction Undergoing Primary PCI
}

\author{
Vlad BATAILA' ${ }^{1,2}$, Nicoleta POPA-FOTEA ${ }^{1,2}$, Sebastian ONCIUL ${ }^{1,2}$, Lucian CALMAC ${ }^{1,2}$, \\ Alexandru SCAFA-UDRISTE ${ }^{1,2}$, Ali CHERRY², Diana STANCIULESCU², Maria DOROBANTU ${ }^{1,2}$
}

\begin{abstract}
Ischemic heart disease is one of the most prevalent diseases with a high impact on mortality and morbidity. The main process implicated in acute coronary syndromes (ACS) including its most severe form, the ST elevation myocardial infarction (STEMI), is the development of thrombosis subsequently of plaque erodation or rupture. The thrombus is formed by aggregates of platelets that furthermore drive the process of coagulation, that in this turn stimulates platelet aderation and aggregation, causing a vicious circle. From these physiopathological mechanims derive the indication and role of antiplatelets and anticoagulation in STEMI. Antiplatelets and anticoagulants play a central role in the therapeutic management of STEMI along with the interventional therapy. Correctly conducted by all physicians involved in the management of patients with STEMI, it reduces the area of ischemia, as well as mortality and other major adverse cardiovascular events. The following article will review the antithrombotic treatment adjuvant to the interventional treatment and the evidence based indications for treatment in STEMI.
\end{abstract}

Keywords: acute coronary syndromes, STEMI, antiplatelets, anticoagulants, guidelines, risk-benefit balance, ischemic risk, primary angioplasty.

\section{Rezumat}

Boala cardiacă ischemică este una dintre cele mai prevalente boli cu un impact major asupra mortalității și morbidității. Principalul proces implicat în sindroamele coronariene acute (SCA), incluzând forma sa cea mai severă infarctul miocardic acut cu supradenivelare de segment ST (STEMI), este tromboza ce urmează în general erodării sau rupturii plăcii de aterom. Trombul este format din agregate plachetare care mai departe activează calea coagulării, care la rândul său stimulează aderarea și agregarea plachetară creând un cerc vicios cu potențare reciprocă. Din aceste mecanisme fiziopatologice derivă indicația și rolul tratamentelor antiagregante și anticoagulante în STEMI, terapia antiagregantă împreună cu cea antiacogulantă jucând un rol central în managementul STEMI alături de terapia intervențională. Un tratament corect administrat de către toți medicii implicați ajută la reducerea ariei de ischemie, precum și la scăderea mortalității și a celorlalte evenimente adverse cardiovasculare majore. Articolul reprezintă o revizuire a tratamentului antitrombotic premergător terapiei de reperfuzie intervenționale, precum și a indicațiilor de ghid bazate pe dovezi pentru tratamentul STEMI.

Cuvinte cheie: sindroame coronariene acute, STEMI, antiagregante, anticoagulante, ghiduri, balanța risc-beneficiu, risc ischemic, angioplastie primară.

${ }^{1}$ "Carol Davila" University of Medicine and Pharmacy, Bucharest, Romania

${ }^{2}$ Emergency Clinical Hospital, Bucharest, Romania
Corresponding author.

Sebastian ONCIUL, Emergency Clinical Hospital, 8 Floreasca

Avenue, Bucharest, Romania.

E-mail: sebastian.onciul@gmail.com 


\section{INTRODUCTION}

Despite the decline in ischemic heart disease (IHD) prevalence in the last two-three decades in Western countries $^{1}$, IHD causes approximately one third of deaths in adults over 35 years of age $\mathrm{e}^{2}$. Ischemic heart disease is known to evolve over a long stable period of time, but the likelyhood of unstable episodes still exists, frequently in association with an atherothrombotic event caused by erosion or rupture of the atheroma plaque. ACS present themselves in their highest severity as STEMI. Because of such a high morbimortality burden, intense effort has been made in the research of the best treatment management of STEMI. In present days, the establishment of the so called "STEMI network" comprised of emergency medical service and hospitals with catheterization laboratories capable of around the clock primary coronary angioplasty (PCI) has optimized the STEMI treatment ${ }^{3}$. The primary $\mathrm{PCI}$ is the mainstay of the STEMI treatment management, but it is mandatory to be accompanied by antithrombotic therapy, sometimes administered at first medical contact.

The ST elevation MI occurs most commonly at the level of a vulnerable plaque as a result of rupture or erosion, with exposure of the lipid core. Circulating platelets are activated and come into contact with the matrix extracellular collagen exposed after rupture of the fibrous cap of the plaque ${ }^{4}$. After platelet adhesion, these will overexpress the receptor for glycoprotein IIb/IIIa, where proteins such as fibrinogen and von Willebrand factor will adhere and form the white thrombus. Several receptors from the level of the platelets are involved in their activation, $\mathrm{P} 2 \mathrm{Y} 12$ receptor being one of them, maintaining the prothrombotic and pro-inflammatory factors release. The P2Y12 antagonists such as clopidogrel, prasugrel, ticagrelor inhibit the activation and aggregation of platelets. In addition, there is also an underlying coagulation process activated. These aforementioned are the main mechanisms targeted by drugs modifying thrombogenesis to produce a clinical proved benefit.

\section{ANTIPLATELETS}

\section{Aspirin}

Aspirin, classified in the class of nonsteroidal antiinflamatory drugs, member of the salicylates family, was first introduced in 1899, its beneficial effects depending on the dose administrated: low doses (75-100 mg/ day) inhibits ireversibly cyclooxigenase-1 (COX-1), preventing the formation of various prostanoids such as tromboxan $\mathrm{A} 2$, prostaglandin $\mathrm{H} 2$, thus having an anti-thrombotic effect and intermediate or high doses (650 mg to $4 \mathrm{~g} /$ day) inhibits COX-1 and COX-2, resulting in an effective analgetic and antipyretic effect ${ }^{5}$. Aspirin represents the cornerstone treatment of acute coronary syndromes, irrespective of the further chosen treatment. Data supporting the positive effect of aspirin for ST-elevation segment myocardial infarction (STEMI) came at the beginnings from one study that proved aspirin before or after fibrinolytic treatment reduces mortality with as much as $23 \%$, with a highly significant $p$-value $(p<0.0001)$. Largely from the study mentioned aboved (ISI-2) ${ }^{6}$ were formulated the initial guidelines indications of oral or intravenous admistration of aspirin in the acute phase of STEMI. Although there is a strong indication, class I level of evidence A for aspirin, the initial optimal dose attired numerous controversies in literature. Albeit it has beneficial effects, the high initial dose of aspirin increases considerably the risk of bleeding as it is quickly absorbed into the first portion of the gastrointestinal tract. Even if the plasmatic half-time of aspirin is of only 20 minutes, the inhibition of platelets lasts for roughly ten days, the life-time of platelets, as these continue to produse cyclooxigenase. From these observations, in current practice there should be a careful analysis of the risk-benefit continuum. In the GUSTO I and GUSTO II, no significant differences were noted between the group receving $325 \mathrm{or} 162 \mathrm{mg}$ of aspirin in terms of mortality or other composite end-points, but there was a significantly lower rate of bleedings in the $162 \mathrm{mg}-$ group ${ }^{7}$. More recent studies such as the ACUTE study, also included in the most recent ESC guidelines for the management of acute myocardial infarction in patients with ST-segment elevation 3, showed that a single dose of acetylsalicilic acid intravenously compared with $300 \mathrm{mg}$ orally resulted in a more complete inhibition of platelets aggregation with comparable bleeding risks ${ }^{8}$.

\section{ADP-receptor inhibitors}

\subsection{Clopidogrel}

Clopidogrel is a second-generation irreversible inhibitor of P2Y12 receptor protein from the family of thienopyridines. It was patented in 1982 and approved for medical use in 1998 being currently on the WHO list of the safest and most effective drugs ${ }^{9}$. Clopidogrel followed ticlopidine, the first member of the thienopyridine family, but with a much faster onset of acti- 
on and a reduction of the adverse effects, mainly the hematological adverse effects ${ }^{10}$. The introduction of clopidogrel into medical practice, and shortly thereafter drug-eluting stents (DES), led to the large-scale imposition of interventional revascularization as the first-line treatment of $\mathrm{IHD}^{11}$. Clopidogrel is an inactive pro-drug which, in order to have the expected clinical effect, requires hepatic activation by the metabolizing enzymes of the cytochrome P450 complex in two stages ${ }^{12}$. It has been observed that the variability of the gene encoding P450 gene CYP2C19 synthesis is associated with decreased bioactivation capacity of clopidogrel with potentially catastrophic clinical effects ${ }^{13}$. In parallel with the affect of bioactivation due to genetic polymorphism, it is also influenced by substances that globally affect the activity of cytochrome P450. We mention among the powerful enzymatic inhibitors macrolides, antifungals, grapefruit juice and among the enzymatic inducers, with the increased risk of hemorrhagic risk, St. Jonh's wort and rifampicin ${ }^{14-16}$. Of particular note should be the interactions of clopidogrel with the drugs usually associated in daily-life scenarios. Regarding the association with proton-pump inhibitors, although omeprazole and esomeprazole are mentioned as having potentially the greatest interaction risk $^{17}$, no clinical impact of this combination has been demonstrated $^{18}$. In vivo aggregation tests at patient's bed have defined and quantified resistance to clopidogrel. Platelet hyperreactivity in patients treated with clopidogrel defines clopidogrel resistance and is potentially associated with increased ischemic risk, similarly, the absence of platelet reactivity may be associated with an increased bleeding risk. However, no randomized trials evaluating personalized treatment based on platelet aggregation testing has shown a benefit of such tests and is therefore not routinely recommended ${ }^{17,19}$. Currently, clopidogrel is indicated in the European guidelines in all the treatment stages of ST-segment elevation myocardial infarction (STEMI), both in the pre-hospital treatment and in the case of thrombolytic treatment, as well as in the case of interventional treatment. The current recommendation includes the specific mention of up-stream administration as close to the first medical contact. An observational study and registry studies have shown that administration as close to the first medical contact is associated with a significant decrease in cardiovascular adverse events related to infarction without a significant increase in bleeding risk ${ }^{20-22}$. Due to the potential variability of the antiplatelet effect of clopidogrel and to the multiple in- teractions and genetic polymorphisms, new molecules with an anti-aggregation effect have been developed.

\subsection{Ticagrelor}

Ticagrelor is the natural successor in the class of anti-aggregates. After the emergence of clopidogrel in the treatment of atherosclerotic events, its limitations were highlighted and, at the same time, the need for a new molecule. Ticagrelor is a reversible inhibitor of the P2Y12 receptor for ADP with direct action. Unlike thienopyridines, ticagrelor does not require hepatic activation $^{23}$. However, although not a prodrug, approximately one third of the effect is produced by a hepatic activated metabolizing product. Given the direct effect of ticagrelor, its action is significantly faster compared to clopidogrel and at the same time the nature of the molecule ensures a more potent inhibition of platelet aggregation and activation ${ }^{24}$. The clinical effect of ticagrelor has been demonstrated in patients with ACSs in the phase III of the PLATO study. It has been shown that the administration of ticagrelor for 12 months after a ACS had a significant end-point of death, acute myocardial infarction and stroke compared with clopidogrel (HR 0.84, CI 0.77-0.92). The superiority of ticagrelor came from benefits in reducing the rate of death and acute myocardial infarction. Ticagrelor did not produce a higher rate of major bleeding complications, but this was due to the absence of coronary artery by-pass grafts $(\mathrm{CABG})$-related bleedings ${ }^{25}$. The demonstrated superiority of ticagrelor has led to its inclusion in the European Society of Cardiology guidelines as a first line in the treatment of ACSs and STEMI in particular, before clopidogrel ${ }^{21,26}$. Considering the importance of STEMI treatment in the actual society, research has been carried out regarding the advantage of early administration of ticagrelor in patients with STEMI who will receive invasive treatment. The ATLANTIC study investigated whether early, up-stream administration is beneficial and with acceptable risks compared to administration at the time of intervention. Non-invasive criteria for reperfusion as well as TIMI flow during the coronary angiography diagnosis as main endpoints, as well as hemorrhagic risk were followed. The study showed no difference in terms of both antithrombotic effect and hemorrhagic risk between the two strategies. The time between the administration of ticagrelor in the two lots was only 31 minutes $^{27}$. Therefore, although the administration of an early dose of clopidogrel has been shown to be beneficial, the same cannot be said about ticagrelor. 


\subsection{Prasugrel}

Prasugrel is another thienopyridine-class drug that blocks P2Y12 receptors. Unlike clopidogrel, which has two stages of hepatic activation, prasugrel has a single stage dependent on the cytochrome P450 complex. Its efficacy was demonstrated in the Triton TIMI study 38. Prasugrel has been shown to be superior to clopidogrel in the treatment of patients with ACS, with fewer deaths from any cause, acute myocardial infarction and additional revascularization. On the other hand, patients receiving prasugrel had significantly more blee$\operatorname{ding}^{28}$. A recent study showed that prasugrel was superior to ticagrelor regarding a composite endpoint of death, MI or stroke, in patients with ACS includgin STEMI $^{29}$ (Table 1).

\section{Gpllbllla inhibitors}

Glycoprotein IIbIIIa plays a major role in the haemostasis by regulating the adhesion and aggregation of platelets. It is situated on the surface of platelets and, when activated, it converts and binds multiple molecules of fibrinogen and subsequently to other platelets. It is the final pathway of platelet aggregation ${ }^{30}$. Multiple drugs have been developed to counteract GpIIbIIIa called GP inhibitors (Table 2). They act by preventing the binding of fibrinogen by the GpIIbIIIa molecule causing a major impairment in the aggregation of platelets. There are three GPI molecules used in the setting of primary PCI: abciximab, eptifibatide and tirofiban. Multiple trials have shown that although high, they have a manageable bleeding risk. In combination with fibrinolytics, GPI were not superior to fibrinolytics alone albeit with an increased bleeding risk ${ }^{31,32}$. Regarding the up-stream use of GPI in STEMI patients undergoing primary PCI, a key trial showed no additional benefit regarding cardiovascular death, cardiogenic shock or congestive failure when compared to standard therapy. Furthermore, it significantly increased the bleeding outcome ${ }^{33}$. Nowadays, the use of GPIs is recommended only within catheterization laboratory, in in-procedure bailout cases such as coronary no-reflow or a large thrombus burden ${ }^{3}$. Also, GPIs may have a place in very high risk procedures or when an intense platelet inhibition is needed, for example in STEMI patients that did not or could not receive normal antiplatelet loading doses. Also, in isolated cases, when there is a large ischaemic area at risk, GPIs may be given upstream ${ }^{34}$. When using GPIs it is mandatory to always evaluate the individual bleeding risk of the patient.

\section{ANTICOAGULANTS}

The combination of anticoagulants with antiplatelets has more benefits in terms of morbidity compared with the anti-platelet treatment alone. From the pletora of anticoagulants, the options are: unfractionated heparin (UFH), enoxaprin, fondaparinux and bivalirudin. After primary PCI there is no need for maintaining anticoagulant therapy instead there are other indications of anticoagulation such as atrial fibrillation, left ventricle thrombosis, mechanical valves or as thromboprophylaxis in patients with long periods of bed rest ${ }^{3}$.

\section{Unfractionated heparin}

Heparin is a glycosaminoglycan polysaccharide that binds to antithrombin III protein, which is a powerful inhibitor of factor Xa and IIa. This binding leads to a conformational change in antithrombin III, that accelerates its ability to inactivate these factors leading to an important anticoagulant effect ${ }^{35,36}$.

Table 1. Main characteristics of antiplatelet drugs in STEMI

\begin{tabular}{|l|l|l|l|l|}
\hline Drug name & Aspenter & Clopidogrel & Prasugrel & Ticagrelor \\
\hline Mechanism of action & Inhibition of COX1 & $\begin{array}{l}\text { Antagonist of P2Y12 } \\
\text { receptor }\end{array}$ & $\begin{array}{l}\text { Antagonist of P2Y12 } \\
\text { receptor }\end{array}$ & $\begin{array}{l}\text { Antagonist of P2Y12 } \\
\text { receptor }\end{array}$ \\
\hline Reversibility & No & No & No & Yes \\
\hline Onset of action & $1 \mathrm{~h}$ & $2-8 \mathrm{~h}$ & $30 \mathrm{~min}-4 \mathrm{~h}$ & $30 \mathrm{~min}-4 \mathrm{~h}$ \\
\hline Loading dose & $\begin{array}{l}150-300 \mathrm{mg} \text { orally } \\
\text { or75-250 mg iv }\end{array}$ & $600 \mathrm{mg}$ & $60 \mathrm{mg}$ & $180 \mathrm{mg}$ \\
\hline Maitanance dose & $75-100 /$ day & $75 \mathrm{mg} /$ day & $10 \mathrm{mg}$ mg bid & $90 \mathrm{mog}$. \\
\hline Contraindications & Hypersensitivity & $\begin{array}{l}\text { Hypersensitivity, very } \\
\text { high risk of hemorrhage }\end{array}$ & $\begin{array}{l}\text { Stroke/transient ischemic } \\
\text { stroke, patients on oral } \\
\text { anticoagulants, patients } \\
\text { with moderate-to-severe } \\
\text { liver disease hypersensitivity }\end{array}$ & $\begin{array}{l}\text { Hem oral anticoagulants, or } \\
\text { in patients with moderate- } \\
\text { to-severe liver disease, } \\
\text { hypersensitivity }\end{array}$ \\
\hline
\end{tabular}


Antithrombotic Therapy in Patients with ST-segment Elevation Myocardial Infarction Undergoing Primary PCI

Table 2. Main characteristics of glycoprotein Ilb/Illa inhibitors

\begin{tabular}{|l|l|l|l|}
\hline \hline & Abciximab & Eptifibatide & Tirofiban \\
\hline Molecule type & $\begin{array}{l}\text { Monoclonal antibody } \\
\text { Large molecule }\end{array}$ & Small & Small \\
\hline Effective half life & $\begin{array}{l}8-12 \mathrm{~h} \\
72 \mathrm{~h} \text { to normal platelet function }\end{array}$ & $\begin{array}{l}2.5 \mathrm{~h} \\
3-4 \mathrm{~h} \text { to normal platelet function }\end{array}$ & $\begin{array}{l}2 \mathrm{~h} \\
\text { 4h to normal platelet function }\end{array}$ \\
\hline Dosing & $\begin{array}{l}\text { Bolus: } 0.25 \mathrm{mg} / \mathrm{kg} \\
\text { Inf:: } 0.125 \mathrm{mg} / \mathrm{kg} / \mathrm{min} 12 \mathrm{~h}\end{array}$ & $\begin{array}{l}\text { Double bolus } 10 \mathrm{~min} \text { appart: } \\
180 \mathrm{mcg} / \mathrm{kg} \\
\text { Inf.: } 2 \mathrm{mcg} / \mathrm{kg} / \mathrm{min} 18 \mathrm{~h}\end{array}$ & $\begin{array}{l}25 \mathrm{mcg} / \mathrm{kg} \text { in } 3 \mathrm{~min} \\
\text { Inf.: } 0.15 \mathrm{mcg} / \mathrm{kg} / \mathrm{min} 18 \mathrm{~h}\end{array}$ \\
\hline $\begin{array}{l}\text { Dose adjustment in } \\
\text { renal disease }\end{array}$ & No; higher risk of bleeding & $\begin{array}{l}\text { CKD III: Inf. dose } 1 \mathrm{mcg} / \mathrm{kg} / \mathrm{min} \\
\text { Not to be administered in CKD IV } \\
\text { and V }\end{array}$ & $\begin{array}{l}\text { CKD IV: 0.05mcg } / \mathrm{kg} / \mathrm{min} \\
\text { Not to be administered in CKD IV }\end{array}$ \\
\hline Reversibility & No & No \\
\hline
\end{tabular}

Present day medical guidelines recommend unfractioned heparin as first choice of anticoagulation treatment in patients with STEMI undergoing primary $\mathrm{PCI}^{21}$. It is the most widely used anticoagulant agent in Europe with excellent cost-effectiveness ${ }^{37}$ and with a long tradition and ease of use in the cath lab. Its effect is usually monitored, especially during long procedures with the activating clotting time test. European Society of Cardiology guidelines clearly define doses of heparin with 70-100 U/kg when used alone and 50-70 U/ $\mathrm{kg}$ when used together with GpIIbIIIa inhibitor. Because of its usually short half time, an ACT test should be performed after 45 minutes to one hour after administration and additional heparin should be given for a target ACT of 200-300 seconds ${ }^{3,26}$.

Its main action is to impede thrombus formation in the intravascular materials used during the procedure e.g. the vascular sheath, the catheters and most importantly in situ inside the aorta or the coronary circulation with deleterious effects. Also, heparin hinders the formation of new thrombus at the site of the coronary obstruction. Having in mind that patients arrive at the cath lab faster than the dual antiplatelet therapy is active, heparin is oftenly the only active antithrombotic drug during the procedure. For the same reasons, heparin impedes acute stent thrombosis during the gap of time between the end of the procedure and the coming of the full efect of antiplatelet drugs ${ }^{38}$. It is most widely used in the setting of the immediate primary PCI, usually in the cath lab. There are some reports that heparin is used up-stream, during first medical contact, when the STEMI diagnosis is established, but usually in isolated cases or local protocols of medical practice ${ }^{36}$.

\section{Low molecular weight heparin}

Low molecular weight heparin (LMWH) is derived from heparin molecules but with shorter polysaccha- ridic structures, modifying its pharmacokinetic properties, with a good subcutaneously absorbtion and a longer half-life. The probability of side-effects as heparin-induced thrombocytopenia are reduced with LMWH. Among the low molecular weight heparins, the most utilised and with a more convenient profile is enoxaparin. In ATOLL trial, intravenous enoxaparin was superior to unfractionated heparin in reducing all endpoints such as ischaemic endpoints, mortality and major bleeding events ${ }^{39}$, the same pinpointed by a meta-analysis with more than 20 studies $^{40}$. From all of the above, enoxaparin was recommended to be taken into consideration in the 2017 STEMI management as class II level of evidence $\mathrm{A}^{39,40}$.

\section{Bivalirudin}

Bivalirudin is a syntetic congener of its natural version, hirudin, having a direct inhibitor effect on thrombin, but also on thrombin-dependent platelet activation and aggregation. It has a short half-life of 25 minutes and a rapid onset of action. It is administered iv with a $0.75 \mathrm{mg} / \mathrm{kg}$ bolus and then followed by a $1.75 \mathrm{mg} / \mathrm{kg} /$ hour in infusion for up to 4 hours. It does not produce nor affects the risk of heparin induced thrombocytopenia, one of the most serious limitations of heparin. Because of a very short half-life, it potentially leads to reduced bleeding complications and also to a better management of the bleeding. Bivalirudine cornerstone trials showed better outcomes regarding bleeding risk and one month to one year mortality rates with similar outcome regarding target-vessel revascularization, when compared to a combination of heparin and GpIIbIIIa or heparin alone. Bivalirudin showed a small but sustained risk af acute stent thrombosis in all trials ${ }^{41,42}$. In modern clinical practice, the radial approach in primary PCI setting showed a marked decrease of bleeding complications regarding the vascular 
access with subsequent impact on mortality itself ${ }^{43}$. Recent trials and meta-analysis compared bivalirudin and heparin in STEMI patients undergoind primary PCI with mostly radial acces. They showed that bivalirudine is not superior to heparin regarding the bleeding risk and mortality, but even with a slight increase of adverse events related to acute stent thrombosis ${ }^{38,44}$.

\section{CONCLUSIONS}

The correct use of antiplatelets and anticoagulants in the setting of STEMI patients undergoing primary PCI is essential for obtaining the optimal benefits such as the reduction of morbi-mortality and also the social and financial burden. Also, a patient-centered therapy must be conducted as the benefits of reducing the ischemic area not to exceed the bleeding risks in some patients. Aspirin, along with new, more potent antiplatelet therapy (such as ticagrelor and prasugrel)

\section{References}

1. Knuuti J, Wijns W, Saraste A. 2019 ESC Guidelines for the diagnosis and management of chronic coronary syndromes. Eur Heart J. 2019 Aug;1-71.

2. Townsend N, Nichols M, Scarborough P, Rayner M. Cardiovascular disease in Europe - Epidemiological update 2015. Eur Heart J. 2015;37(42):3232-45.

3. Ibanez B, James S, Agewall S, Antunes MJ, Bucciarelli-Ducci $\mathrm{C}$, Bueno $\mathrm{H}$, et al. 2017 ESC Guidelines for the management of acute myocardial infarction in patients presenting with ST-segment elevation. Eur Heart J. 2018;39(2):119-77.

4. Hamm C, Heeschen C, Falk E, Fox K. Acute Coronary Syndromes: Pathophysiology, Diagnosis and Risk Stratification. 2nd ed. Cam AJ, Lüscher TF SP, editor. Oxford: Oxford University Press; 2009. 333-366 p.

5. Tohgi H, Konno S, Tamura K, Kimura B, Kawano K. Effects of low-to-high doses of aspirin on platelet aggregability and metabolites of thromboxane A2 and prostacyclin. Stroke. 1992 Oct;23(10):1400-3.

6. Randomised trial of intravenous streptokinase, oral aspirin, both, or neither among 17,187 cases of suspected acute myocardial infarction: ISIS-2. ISIS-2 (Second International Study of Infarct Survival) Collaborative Group. Lancet (London, England). 1988 Aug;2(8607):349-60.

7. Berger JS, Stebbins A, Granger CB, Ohman EM, Armstrong PW, Van de Werf F, et al. Initial aspirin dose and outcome among STelevation myocardial infarction patients treated with fibrinolytic therapy. Circulation. 2008 Jan; 117(2):192-9.

8. Zeymer U, Hohlfeld T, Dahl J vom, Erbel R, Münzel T, Zahn R, et al. Prospective, randomised trial of the time dependent antiplatelet effects of $500 \mathrm{mg}$ and $250 \mathrm{mg}$ acetylsalicylic acid i. v. and $300 \mathrm{mg}$ p. o. in ACS (ACUTE). Thromb Haemost [Internet]. 2017 Nov 28 [cited 2019 Sep 14];117(03):625-35. Available from: http://www.ncbi.nlm.nih.gov/pubmed/28102427 and heparin will likely remain the standard of medical care for STEMI patients in the foreseeable future. They are successful drugs, proved to be life-saving in acute coronary syndromes and STEMI as adjuvants to the interventional approach. It is mandatory for all medical personnel involved in the management of patients with STEMI to be very familiar with these drugs, their doasge and side effects. New research regarding timely coronary reperfusion is ongoing and we should be looking forward to improving our knowledge in treatment strategies.

Compliance with ethics requirements: The authors declare no conflict of interest regarding this article. The authors declare that all the procedures and experiments of this study respect the ethical standards in the Helsinki Declaration of 1975, as revised in 2008(5), as well as the national law. Informed consent was obtained from all the patients included in the study.

9. WHO Model List of Essential Medicines [Internet]. 2017 [cited 2019 May 4]. Available from: http://www.who.int/medicines/ publications/essentialmedicines/en/

10. Eshaghian S, Kaul S, Amin S, Shah PK, Diamond GA. Role of clopidogrel in managing atherothrombotic cardiovascular disease. Ann Intern Med. 2007 Mar; 146(6):434-41.

11. Iqbal J, Gunn J, Serruys PW. Coronary stents: historical development, current status and future directions. Br Med Bull [Internet]. 2013 Mar 26;106(1):193-211. Available from: https://doi. org/10.1093/bmb/ldt009

12. Kazui M, Nishiya Y, Ishizuka T, Hagihara K, Farid NA, Okazaki O, et al. Identification of the human cytochrome P450 enzymes involved in the two oxidative steps in the bioactivation of clopidogrel to its pharmacologically active metabolite. Drug Metab Dispos. 2010 Jan;38(1):92-9.

13. Holmberg MT, Tornio A, Neuvonen M, Neuvonen PJ, Backman JT, Niemi M. Grapefruit juice inhibits the metabolic activation of clopidogrel. Clin Pharmacol Ther. 2014 Mar;95(3):307-13.

14. Lau WC, Waskell LA, Watkins PB, Neer CJ, Horowitz K, Hopp $A S$, et al. Atorvastatin reduces the ability of clopidogrel to inhibit platelet aggregation: a new drug-drug interaction. Circulation. 2003 Jan;107(1):32-7.

15. Lau WC, Welch TD, Shields T, Rubenfire M, Tantry US, Gurbel PA. The effect of St John's Wort on the pharmacodynamic response of clopidogrel in hyporesponsive volunteers and patients: increased platelet inhibition by enhancement of CYP3A4 metabolic activity. J Cardiovasc Pharmacol. 2011 Jan;57(1):86-93.

16. Muller I, Besta F, Schulz C, Li Z, Massberg S, Gawaz M. Effects of statins on platelet inhibition by a high loading dose of clopidogrel. Circulation. 2003 Nov; 108(18):2195-7.

17. Valgimigli M, Bueno H, Byrne RA, Collet J-P, Costa F, Jeppsson $A$, et al. 2017 ESC focused update on dual antiplatelet therapy in coronary artery disease developed in collaboration with EACTS: 
The Task Force for dual antiplatelet therapy in coronary artery disease of the European Society of Cardiology (ESC) and of the European . Eur Heart J [Internet]. 2017 Aug 26;39(3):213-60. Available from: https://doi.org/10.1093/eurheartj/ehx419

18. Bhatt DL, Cryer BL, Contant CF, Cohen M, Lanas A, Schnitzer TJ, et al. Clopidogrel with or without omeprazole in coronary artery disease. N Engl J Med. 2010 Nov;363(20):1909-17.

19. Collet J-P, Cuisset T, Range G, Cayla G, Elhadad S, Pouillot C, et al. Bedside monitoring to adjust antiplatelet therapy for coronary stenting. N Engl J Med. 2012 Nov;367(22):2100-9.

20. Koul S, Smith JG, Schersten F, James S, Lagerqvist B, Erlinge D. Effect of upstream clopidogrel treatment in patients with ST-segment elevation myocardial infarction undergoing primary percutaneous coronary intervention. Eur Heart J. 2011 Dec;32(23):2989-97.

21. Ibanez B, James S, Agewall S, Antunes MJ, Bucciarelli-Ducci C, Bueno H, et al. 2017 ESC Guidelines for the management of acute myocardial infarction in patients presenting with ST-segment elevation: The Task Force for the management of acute myocardial infarction in patients presenting with ST-segment elevation of the European Socie. Eur Heart J [Internet]. 2017 Aug 26;39(2):119-77. Available from: https://doi.org/10.1093/ eurheartj/ehx393

22. Zeymer U, Arntz H-R, Mark B, Fichtlscherer S, Werner G, Scholler $R$, et al. Efficacy and safety of a high loading dose of clopidogrel administered prehospitally to improve primary percutaneous coronary intervention in acute myocardial infarction: the randomized CIPAMI trial. Clin Res Cardiol. 2012 Apr;101(4):305-12.

23. Teng R, Oliver S, Hayes MA, Butler K. Absorption, Distribution, Metabolism, and Excretion of Ticagrelor in Healthy Subjects. Drug Metab Dispos [Internet]. 2010 Sep 1;38(9):1514 LP - 1521. Available from: http://dmd.aspetjournals.org/content/38/9/1514.abstract

24. Jiang X-L, Samant S, Lesko LJ, Schmidt S. Clinical pharmacokinetics and pharmacodynamics of clopidogrel. Clin Pharmacokinet [Internet]. 2015 Feb;54(2):147-66. Available from: https:// www.ncbi.nlm.nih.gov/pubmed/25559342

25. Velders MA, Abtan J, Angiolillo DJ, Ardissino D, Harrington RA, Hellkamp A, et al. Safety and efficacy of ticagrelor and clopidogrel in primary percutaneous coronary intervention. Heart [Internet]. 2016 Apr 15;102(8):617 LP - 625. Available from: http:// heart.bmj.com/content/102/8/617.abstract

26. Neumann F-J, Sousa-Uva M, Ahlsson A, Alfonso F, Banning AP, Benedetto U, et al. 2018 ESC/EACTS Guidelines on myocardial revascularization. Eur Heart J [Internet]. 2018 Aug 25;40(2):87165. Available from: https://doi.org/10.1093/eurheartj/ehy394

27. Montalescot G, van 't Hof AW, Lapostolle F, Silvain J, Lassen JF, Bolognese L, et al. Prehospital Ticagrelor in ST-Segment Elevation Myocardial Infarction. N Engl J Med [Internet]. 2014 Sep 1;371(11):1016-27. Available from: https://doi.org/10.1056/ NEJMoa1407024

28. Wiviott SD, Braunwald E, McCabe CH, Montalescot G, Ruzyllo W, Gottlieb S, et al. Prasugrel versus Clopidogrel in Patients with Acute Coronary Syndromes. N Engl J Med [Internet]. 2007 Nov 15;357(20):2001-15. Available from: https://doi.org/10.1056/ NEJMoa0706482

29. Schüpke S, Neumann F-J, Menichelli M, Mayer K, Bernlochner I, Wöhrle J, et al. Ticagrelor or Prasugrel in Patients with Acute Coronary Syndromes. N Engl J Med [Internet]. 2019 Sep 1 [cited 2019 Sep 14];NEJMoa1908973. Available from: http://www. nejm.org/doi/10.1056/NEJMoa1908973

30. Kristensen S, Würtz M, Grove E, Caterina R, Huber K, Moliterno $\mathrm{D}$, et al. Contemporary use of glycoprotein IIb/IIla inhibitors. Thromb Haemost [Internet]. 2012 Nov 29 [cited 2019 Sep 14];107(02):215-24. Available from: http://www.thieme-connect.de/DOI/DOI?10.1160/TH11-07-0468
31. The Assessment of the Safety and Efficacy of a New Thrombolytic Regimen (ASSENT)-3 Investigators. Efficacy and Safety of Tenecteplase in Combination With Enoxaparin, Abciximab, or Unfractionated Heparin: The ASSENT-3 Randomized Tria in Acute MI - American College of Cardiology [Internet]. [cited 2019 Sep 14]. Available from: https://www.acc.org/latest-incardiology/clinical-trials/2010/02/22/18/40/assent-3

32. The GUSTO V Randomised Trial - American College of Cardiology [Internet]. [cited 2019 Sep 14]. Available from: https://www. acc.org/latest-in-cardiology/clinical-trials/2010/02/23/19/06/ gusto-V

33. Ellis SG, Tendera M, de Belder MA, van Boven AJ, Widimsky P, Janssens $\mathrm{L}$, et al. Facilitated $\mathrm{PCl}$ in Patients with ST-Elevation Myocardial Infarction. N Engl J Med [Internet]. 2008 May 22 [cited 2019 Sep 14];358(21):2205-17. Available from: http://www. nejm.org/doi/abs/10.1056/NEJMoa0706816

34. De Luca L, Colivicchi F, Gulizia MM, Pugliese FR, Ruggieri MP, Musumeci $G$, et al. Clinical pathways and management of antithrombotic therapy in patients with acute coronary syndrome (ACS): a Consensus Document from the Italian Association of Hospital Cardiologists (ANMCO), Italian Society of Cardiology (SIC), Italian Society of Emergency Medicine (SIMEU) and Italian Society of Interventional Cardiology (SICI-GISE). Eur Heart J Suppl [Internet]. 2017 May [cited 2019 Sep 14];19(Suppl D):D130-50. Available from: http://www.ncbi.nlm.nih.gov/pubmed/28751840

35. Shriver Z, Capila I, Venkataraman G, Sasisekharan R. Heparin and heparan sulfate: analyzing structure and microheterogeneity. Handb Exp Pharmacol [Internet]. 2012 [cited 2019 Sep 14];(207):159-76. Available from: http://www.ncbi.nlm.nih.gov/ pubmed/22566225

36. Hermanides RS, Kilic S, van 't Hof AWJ. Optimal pharmacological therapy in ST-elevation myocardial infarction-a review: A review of antithrombotic therapies in STEMI. Netherlands Hear J. 2018;26(6):296-310.

37. Deharo P, Johnson TW, Rahbi H, Kandan R, Bowles R, Mozid A, et al. Bivalirudin versus heparin in primary PCl: clinical outcomes and cost analysis. Open Hear [Internet]. 2018 May 10 [cited 2019 Sep 14];5(1):e000767. Available from: http://openheart. bmj.com/lookup/doi/10.1136/openhrt-2017-000767

38. EIGuindy AM. HEAT-PPCI: A clear and welcome win for heparin. Glob Cardiol Sci Pract. 2014;2014(1):7

39. Montalescot G, Zeymer U, Silvain J, Boulanger B, Cohen $M$ Goldstein $P$, et al. Intravenous enoxaparin or unfractionated heparin in primary percutaneous coronary intervention for STelevation myocardial infarction: the international randomised open-label ATOLL trial. Lancet [Internet]. 2011 Aug [cited 2019 Sep 5];378(9792):693-703. Available from: https://linkinghub. elsevier.com/retrieve/pii/S0140673611608763

40. Silvain J, Beygui F, Barthelemy O, Pollack C, Cohen M, Zeymer U, et al. Efficacy and safety of enoxaparin versus unfractionated heparin during percutaneous coronary intervention: systematic review and meta-analysis. BMJ [Internet]. 2012 Feb 13 [cited 2019 Sep 5];344(feb03 1):e553-e553. Available from: http:// www.ncbi.nlm.nih.gov/pubmed/22306479

41. Stone GW, Witzenbichler B, Guagliumi G, Peruga JZ, Brodie BR, Dudek $\mathrm{D}$, et al. Bivalirudin during Primary $\mathrm{PCl}$ in Acute Myocardial Infarction. N Engl J Med [Internet]. 2008 May 22 [cited 2019 Sep 5];358(21):2218-30. Available from: http://www.ncbi.nlm. nih.gov/pubmed/18499566

42. Mehran R, Lansky AJ, Witzenbichler B, Guagliumi G, Peruga $\mathrm{JZ}$, Brodie BR, et al. Bivalirudin in patients undergoing primary angioplasty for acute myocardial infarction (HORIZONS-AMI) 1 -year results of a randomised controlled trial. Lancet [Internet]. 2009 Oct 3 [cited 2019 Sep 5];374(9696):1149-59. Available from: http://www.ncbi.nlm.nih.gov/pubmed/19717185 
Vlad BATAILA et al.

43. Mason PJ, Shah B, Tamis-Holland JE, Bittl JA, Cohen MG, Safirstein J, et al. An Update on Radial Artery Access and Best Practices for Transradial Coronary Angiography and Intervention in Acute Coronary Syndrome: A Scientific Statement From the American Heart Association. Circ Cardiovasc Interv [Internet]. 2018 Sep [cited 2019 Sep 5];11(9). Available from: https://www. ahajournals.org/doi/10.1161/HCV.0000000000000035
44. Shahzad A, Kemp I, Mars C, Wilson K, Roome C, Cooper R, et al. Unfractionated heparin versus bivalirudin in primary percutaneous coronary intervention (HEAT-PPCI): an open-label, single centre, randomised controlled trial. Lancet (London, England) [Internet]. 2014 Nov 22 [cited 2019 Sep 5];384(9957):1849-58 Available from: http://www.ncbi.nlm.nih.gov/pubmed/25002178 